\title{
THE NUCLEOTIDE NITROGEN CONTENT OF PATHOLOGIC HUMAN WHOLE BLOOD ${ }^{1,2}$
}

\author{
By FRANK WORTHINGTON ALLEN, SALVATORE P. LUCIA AND JOHN J. EILER
}

(From the Divisions of Biochemistry (Berkeley) and Medicine (San Francisco), University of California Medical School)

(Received for publication October 3, 1935)

Recent investigations suggest that the following properties may be attributed to the purine nucleotides: (1) the apparent ability to stimulate leukocytopoiesis, (2) the ability to produce interference in conduction in the heart, (3) the ability to produce increased tone in isolated smooth muscle, and (4) participation in the co-ferment complex where the catabolism of carbohydrate is involved. Only those nucleotides which contain the component, adenine, display the latter. three properties.

Since the nucleotide of the blood contains adenine as its purine component, it would seem to be of value to study the possible quantitative variations in this nucleotide under various pathological conditions. Only two other investigations of this nature have been attempted, that of Rothmann (1), completed before adequate quantitative methods were available, and that of Buell (2), which has been published during the preparation of this manuscript.

Buell (3) has recently revised the Buell and Perkins' (4) method for the estimation of the nucleotide content of the blood. Her paper contains data which were obtained from the analyses of 107 blood samples. The average nucleotide nitrogen content per $100 \mathrm{cc}$. of whole blood for normal males was found to be $6.2 \mathrm{mgm}$.; for normal females, 5.2 mgm.

It is generally accepted that, apart from the phospholipins, the " ester phosphorus" compounds of the blood, which include the nucleotides, are, under normal conditions, practically confined to the red blood corpuscles. Buell (3) presents evidence to show that "the apparent difference between the sexes in the nucleotide content of whole blood is associated with the fact that males have more red corpuscles and a correspondingly greater

1 Aided by a grant from the Research Board of the University.

2 Aided by a grant given in memory of Laurence $\mathbf{A}$. Myers, Jr., and Thomas J. Maxwell. volume of red cells per unit volume of whole blood than do females." This is undoubtedly true under normal conditions where the number and volume of the red blood corpuscles in comparison

TABLE I

Nucleotide nitrogen content of the whole blood of patients with various pathological conditions

\begin{tabular}{|c|c|c|c|c|c|}
\hline $\begin{array}{l}\text { Case } \\
\text { num- } \\
\text { bert }\end{array}$ & $\begin{array}{c}\text { Nuoleotide } \\
\text { nitrogen } \\
\text { per } 100 \mathrm{oc} . \\
\text { whole } \\
\text { blood }\end{array}$ & $\begin{array}{c}\text { Hemo- } \\
\text { glo- } \\
\text { bin }\end{array}$ & $\begin{array}{c}\text { Red } \\
\text { blood } \\
\text { corpus- } \\
\text { cles }\end{array}$ & $\begin{array}{l}\text { White } \\
\text { blood } \\
\text { cells }\end{array}$ & Diagnosis \\
\hline & mom. & $\begin{array}{l}\text { per } \\
\text { cent }\end{array}$ & millions & & \\
\hline \multicolumn{6}{|c|}{ Male } \\
\hline $\begin{array}{c}6 a^{*} \\
6 b^{*} \\
6 c^{*} \\
6 d \\
6 e \\
6 f \\
26 a^{*} \\
26 b \\
260 \\
26 d \\
26 \mathrm{~d} \\
65 \mathrm{a} \\
65 \mathrm{~b} \\
108\end{array}$ & $\begin{array}{l}2.6 \\
2.7 \\
3.8 \\
4.6 \\
3.7 \\
4.9 \\
2.4 \\
2.5 \\
3.7 \\
4.1 \\
4.6 \\
2.5 \\
3.3 \\
2.9\end{array}$ & $\begin{array}{l}37 \\
33 \\
47 \\
81 \\
66 \\
90 \\
31 \\
42 \\
68 \\
70 \\
75 \\
43 \\
64 \\
45\end{array}$ & $\begin{array}{l}1.38 \\
1.50 \\
1.85 \\
3.90 \\
3.95 \\
4.30 \\
1.26 \\
2.05 \\
2.73 \\
4.28 \\
4.38 \\
1.64 \\
2.55 \\
1.51\end{array}$ & $\begin{array}{l}3,400 \\
2,800 \\
4,280 \\
\mathbf{5 , 7 6 0} \\
\mathbf{9 , 0 0 0} \\
\mathbf{5 , 4 2 0} \\
\mathbf{4 , 5 0 0} \\
\mathbf{7 , 4 5 0} \\
\mathbf{7 , 5 5 0} \\
\mathbf{5 , 7 0 0} \\
\mathbf{6 , 7 0 0} \\
\mathbf{7 , 7 0 0} \\
\mathbf{9 , 0 0 0} \\
\mathbf{7 , 7 5 0}\end{array}$ & $\begin{array}{l}\text { Perniolous anemia } \\
\text { Pernioious anemia } \\
\text { Pernioious anemia } \\
\text { Pernicious anemia } \\
\text { Pernicious anemia } \\
\text { Pernicious anemia } \\
\text { Perniolous anemia } \\
\text { Pernicious anemia } \\
\text { Pernicious anemia } \\
\text { Pernicious anemia } \\
\text { Pernicious anemia } \\
\text { Pernicious anemia } \\
\text { Pernicious anemia } \\
\text { Pernioious anemia }\end{array}$ \\
\hline \multicolumn{6}{|c|}{ Female } \\
\hline $\begin{array}{l}17 \mathrm{a}^{*} \\
17 \mathrm{~b}^{*} \\
17 \mathrm{o}^{*} \\
17 \mathrm{~d}^{*} \\
\mathbf{3 0} \\
38^{*} \\
\mathbf{7 5}\end{array}$ & $\begin{array}{l}2.5 \\
2.4 \\
2.2 \\
5.2 \\
3.3 \\
1.6 \\
2.8\end{array}$ & $\begin{array}{l}44 \\
38 \\
44 \\
55 \\
60 \\
24 \\
28\end{array}$ & $\begin{array}{l}1.78 \\
1.50 \\
2.15 \\
2.83 \\
3.02 \\
0.82 \\
0.97\end{array}$ & $\begin{array}{l}3,500 \\
2,800 \\
2,350 \\
4,200 \\
8,600 \\
4,800 \\
6,650\end{array}$ & $\begin{array}{l}\text { Pernicious anemia } \\
\text { Pernicious anemia } \\
\text { Pernicious anemia } \\
\text { Pernicious anemia } \\
\text { Pernicious anemia } \\
\text { Pernicious anemia } \\
\text { Pernicious anemis }\end{array}$ \\
\hline \multicolumn{6}{|c|}{ Male } \\
\hline $\begin{array}{c}2 \\
9 \\
14 \\
23 \\
14 b \\
43 \\
66 \\
69 \\
81 \\
84 \\
106 \\
109\end{array}$ & $\begin{array}{l}3.5 \\
4.9 \\
5.0 \\
5.0 \\
6.1 \\
2.6 \\
6.2 \\
5.1 \\
4.6 \\
7.8 \\
3.0 \\
4.1\end{array}$ & $\begin{array}{l}82 \\
85 \\
85 \\
60 \\
86 \\
60 \\
90 \\
85 \\
61 \\
93 \\
45 \\
90\end{array}$ & $\begin{array}{l}\mathbf{3 . 9 7} \\
\mathbf{4 . 3 6} \\
\mathbf{4 . 8 8} \\
\mathbf{3 . 3 4} \\
4.75 \\
\mathbf{2 . 8 0} \\
\mathbf{5 . 0 0} \\
\mathbf{5 . 1 0} \\
\mathbf{3 . 3 1} \\
\mathbf{6 . 0 0} \\
\mathbf{2 . 3 0} \\
\mathbf{3 . 7 0}\end{array}$ & $\begin{array}{r}900 \\
4,150 \\
2,800 \\
1,000 \\
2,550 \\
1,520 \\
4,200 \\
2,400 \\
2,900 \\
4,400 \\
1,250 \\
1,960\end{array}$ & $\begin{array}{l}\text { Lymphosarcomatosis with multi- } \\
\text { ple skin nodules. Leukopenia } \\
\text { Bronohopneumonia } \\
\text { Loukopenia, after x-ray } \\
\text { Leukopenis } \\
\text { Leukopenia, after x-ray } \\
\text { Lymphoblastoms } \\
\text { Eosinophilis } \\
\text { Asthma. Lobar pneumonia } \\
\text { Hemolytio jaundioe } \\
\text { Arteriosolerotio gangrene } \\
\text { Lymphatio leukemia } \\
\text { Phenol polsoning. Lobar pnou- } \\
\text { monla }\end{array}$ \\
\hline \multicolumn{6}{|c|}{ Pemale } \\
\hline 89 & 3.8 & 80 & 4.48 & 4,250 & Cholecystitis \\
\hline
\end{tabular}


TABLE I-Continued

\begin{tabular}{c|c|c|c|c|c}
\hline $\begin{array}{c}\text { Case } \\
\text { num- } \\
\text { bert }\end{array}$ & $\begin{array}{c}\text { Nucleotide } \\
\text { nitrogen } \\
\text { per 100 ce. } \\
\text { whole } \\
\text { blood }\end{array}$ & $\begin{array}{c}\text { Hemo- } \\
\text { glo- } \\
\text { bin }\end{array}$ & $\begin{array}{c}\text { Red } \\
\text { blood } \\
\text { corpus- } \\
\text { cles }\end{array}$ & $\begin{array}{c}\text { White } \\
\text { blood } \\
\text { cells }\end{array}$ & Diagnosis \\
\hline mgm. & $\begin{array}{c}\text { per } \\
\text { cent }\end{array}$ & millions & & \\
\hline
\end{tabular}

\begin{tabular}{c|r|r|r|r|l}
\hline \multicolumn{5}{c}{ Male } \\
\hline 1 & 3.7 & 36 & 1.92 & 110,000 & Myeloid leukemia \\
18 & 7.1 & 27 & 2.00 & 250,000 & Myeloid leukemia \\
31 & 7.4 & 95 & 5.28 & 14,650 & Lymphatic leukemia \\
34 & 4.8 & 70 & 3.55 & 8,450 & Aleukemic lymphatic leukemia \\
62 & 6.4 & 55 & 3.06 & 175,000 & Myeloid leukemia \\
82 & 2.9 & 78 & 4.19 & 13,050 & Lymphoblastoma. Leukemia cutis \\
$86 \mathrm{a}$ & 6.7 & 65 & 3.60 & 156,000 & Myeloid leukemia \\
$86 \mathrm{~b}$ & 8.7 & 71 & 3.68 & 140,800 & Myeloid leukemia \\
$86 \mathrm{c}$ & 11.3 & 65 & 4.64 & 350,000 & Myeloid leukemia \\
96 & 10.2 & 45 & 2.90 & 530,000 & Myeloid leukemia \\
$106 \mathrm{a} \dagger$ & 3.0 & 45 & 2.30 & 1,250 & Lymphatic leukemia \\
$106 \mathrm{~b}$ & 4.2 & 67 & 3.33 & 38,000 & Lymphatic leukemia \\
\hline
\end{tabular}

Female

\begin{tabular}{l|l|l|l|l|l}
\hline $20 \mathrm{a}$ & 8.5 & 42 & 2.32 & 370,000 & Myeloid leukemia \\
$20 \mathrm{~b}$ & 6.2 & 40 & 2.90 & 232,000 & Myeloid leukemia \\
$20 \mathrm{c}$ & 4.8 & 40 & 2.16 & 290,000 & Myelold leukemia \\
24 & 6.2 & 63 & 3.35 & 96,000 & Monocytic leukemia \\
72 & 3.5 & $\mathbf{9 2}$ & $\mathbf{5 . 8 4}$ & $\mathbf{2 4 , 6 0 0}$ & Myeloid leukemia \\
$\mathbf{9 3}$ & $\mathbf{5 . 7}$ & $\mathbf{5 5}$ & $\mathbf{2 . 8 5}$ & $\mathbf{9} 500$ & Myeloid leukemia \\
\hline
\end{tabular}

Male

\begin{tabular}{|c|c|c|c|c|c|}
\hline 3 & 5.9 & 118 & 6.30 & 9,500 & Chronic nephritis. Cardiac do- \\
\hline $\begin{array}{l}4 \\
5\end{array}$ & $\begin{array}{l}5.6 \\
4.2\end{array}$ & $\begin{array}{l}93 \\
72\end{array}$ & $\begin{array}{l}4.30 \\
3.90\end{array}$ & $\begin{array}{r}29,600 \\
9,000\end{array}$ & $\begin{array}{l}\text { Purulent empyema } \\
\text { Carcinoma of the stomach with }\end{array}$ \\
\hline 7 & 4.6 & 75 & 3.90 & 8,300 & $\begin{array}{l}\text { Gonorrheal arthritis. Generalized } \\
\text { arteriosclerosis. Interstitial ne- } \\
\text { phritis }\end{array}$ \\
\hline $\begin{array}{r}8 \\
11 \\
12 \\
13 \\
15 \\
16\end{array}$ & $\begin{array}{l}5.4 \\
4.8 \\
6.1 \\
4.7 \\
3.8 \\
7.8\end{array}$ & $\begin{array}{r}85 \\
88 \\
85 \\
60 \\
92 \\
113\end{array}$ & $\begin{array}{l}3.85 \\
4.65 \\
4.94 \\
3.95 \\
4.42 \\
6.37\end{array}$ & $\begin{array}{r}8,600 \\
11,650 \\
32,760 \\
9,600 \\
17,950 \\
9,950\end{array}$ & $\begin{array}{l}\text { Lobar pneumonia } \\
\text { Infectious arthritis } \\
\text { Lobar pneumonia } \\
\text { Gout } \\
\text { Gout } \\
\text { Chronic emphysema. Bronchitis. }\end{array}$ \\
\hline $\begin{array}{l}21 \\
22 \\
25 \\
27 \mathrm{a} \\
27 \mathrm{~b} \\
270 \\
28\end{array}$ & $\begin{array}{l}5.5 \\
5.0 \\
6.2 \\
3.7 \\
3.0 \\
4.6 \\
5.1\end{array}$ & $\begin{array}{l}94 \\
76 \\
84 \\
45 \\
50 \\
43 \\
82\end{array}$ & $\begin{array}{l}5.20 \\
3.63 \\
5.49 \\
2.65 \\
2.59 \\
2.31 \\
4.25\end{array}$ & $\begin{array}{r}17,600 \\
17,050 \\
10,000 \\
9,900 \\
6,800 \\
12,200 \\
\mathbf{5 , 2 8 0}\end{array}$ & $\begin{array}{l}\text { Lobar pneumonia } \\
\text { Lobar pneumonia } \\
\text { Malingerer } \\
\text { Hodgkin's disease } \\
\text { Hodgkin's disease } \\
\text { Hodgkin's disease } \\
\text { Neurofibromatosis (von Reckling- }\end{array}$ \\
\hline 29 & 2.3 & 36 & 1.86 & 14,000 & Chronic pneumonia. Hemolytic \\
\hline $\begin{array}{l}32 \\
36\end{array}$ & $\begin{array}{l}5.7 \\
4.5\end{array}$ & $\begin{array}{l}85 \\
80\end{array}$ & $\begin{array}{l}4.07 \\
4.33\end{array}$ & $\begin{array}{l}8.900 \\
5,600\end{array}$ & $\begin{array}{l}\text { Pellagra } \\
\text { Neurosyphilis. Decompensated }\end{array}$ \\
\hline $\begin{array}{l}37 \\
40\end{array}$ & $\begin{array}{l}2.2 \\
5.3\end{array}$ & $\begin{array}{l}16 \\
90\end{array}$ & $\begin{array}{l}1.35 \\
4.75\end{array}$ & $\begin{array}{r}10,200 \\
6,200\end{array}$ & $\begin{array}{l}\text { Peptic ulcer, posthemorrhagic } \\
\text { Psychasthenia }\end{array}$ \\
\hline
\end{tabular}

with the white blood cells maintain the usual level.

This investigation was undertaken in order to determine the nucleotide nitrogen content of samples of whole blood from pathological cases, and to study the relationships between this factor and the hemoglobin, the red blood corpuscle, and the white blood cell content of the blood.

Over. one hundred pathological cases were selected in order to determine the range of the nucleotide nitrogen content in the blood under some
TABLE I-Continued

\begin{tabular}{|c|c|c|c|c|c|}
\hline $\begin{array}{l}\text { Case } \\
\text { num- } \\
\text { bert }\end{array}$ & $\begin{array}{c}\text { Nucleotide } \\
\text { nitrogen } \\
\text { per } 100 \mathrm{cc} . \\
\text { whole } \\
\text { blood }\end{array}$ & $\begin{array}{c}\text { Hemo- } \\
\text { glo- } \\
\text { bin }\end{array}$ & $\begin{array}{l}\text { Red } \\
\text { blood } \\
\text { corpus- } \\
\text { cles }\end{array}$ & $\begin{array}{l}\text { White } \\
\text { blood } \\
\text { cells }\end{array}$ & Diagnosis \\
\hline & mgm. & $\begin{array}{l}\text { per } \\
\text { cent }\end{array}$ & millions & & \\
\hline \multicolumn{6}{|c|}{ Male } \\
\hline 42 & 5.7 & 75 & 3.87 & 9,950 & Pulmonary tuberculosis. Arterio- \\
\hline $\begin{array}{l}44 \\
45\end{array}$ & $\begin{array}{l}5.7 \\
6.4\end{array}$ & $\begin{array}{l}90 \\
80\end{array}$ & $\begin{array}{l}5.12 \\
4.40\end{array}$ & $\begin{array}{l}5,100 \\
8,160\end{array}$ & Arteriosclerosis. Mitral valvulitis \\
\hline $\begin{array}{l}46 \\
51\end{array}$ & $\begin{array}{l}4.6 \\
4.7\end{array}$ & $\begin{array}{l}82 \\
90\end{array}$ & $\begin{array}{l}3.70 \\
4.93\end{array}$ & $\begin{array}{l}6,100 \\
9,450\end{array}$ & $\begin{array}{l}\text { Rheumatic heart disease } \\
\text { Jacksonian epilepsy. Hyperten- }\end{array}$ \\
\hline $\begin{array}{l}52 \\
53 \\
56 \\
58 \\
61 \\
64 a\end{array}$ & $\begin{array}{l}6.1 \\
7.6 \\
6.0 \\
4.0 \\
4.4 \\
5.2\end{array}$ & $\begin{array}{l}90 \\
95 \\
85 \\
60 \\
85 \\
90\end{array}$ & $\begin{array}{l}5.59 \\
5.90 \\
4.86 \\
3.40 \\
4.45 \\
6.80\end{array}$ & $\begin{array}{r}8,800 \\
8,250 \\
8,200 \\
13,700 \\
9,800 \\
9,800\end{array}$ & $\begin{array}{l}\text { Peptic ulcer. Neurasthenia } \\
\text { Pneumonia (convalescing) } \\
\text { Graves' disease } \\
\text { Malnutrition } \\
\text { Lymphosarcoma } \\
\text { Rheumatic heart disease. Car- }\end{array}$ \\
\hline $\begin{array}{l}64 b \\
70\end{array}$ & $\begin{array}{l}5.8 \\
6.0\end{array}$ & $\begin{array}{r}106 \\
72\end{array}$ & $\begin{array}{l}8.50 \\
3.60\end{array}$ & $\begin{array}{r}11,200 \\
7,960\end{array}$ & $\begin{array}{l}\text { Congenital heart disease } \\
\text { Luetic-hepato-splenomegaly. Mor- } \\
\text { phinism }\end{array}$ \\
\hline $\begin{array}{l}71 \\
73 \\
74\end{array}$ & $\begin{array}{l}5.9 \\
2.7 \\
3.4\end{array}$ & $\begin{array}{l}70 \\
45 \\
73\end{array}$ & $\begin{array}{l}4.84 \\
3.75 \\
4.23\end{array}$ & $\begin{array}{l}9,600 \\
6,800 \\
8,800\end{array}$ & $\begin{array}{l}\text { Hodgkin's disease } \\
\text { Chronic hypochromic anemia } \\
\text { Visceral syphilis. Carcinoma of }\end{array}$ \\
\hline $\begin{array}{l}76 \\
77 \\
79 \\
80\end{array}$ & $\begin{array}{l}6.0 \\
4.5 \\
5.1 \\
6.3\end{array}$ & $\begin{array}{l}80 \\
70 \\
76 \\
75\end{array}$ & $\begin{array}{l}4.78 \\
4.35 \\
4.64 \\
4.25\end{array}$ & $\begin{array}{r}7,050 \\
10,900 \\
6,400 \\
7,240\end{array}$ & $\begin{array}{l}\text { Bronchiectasis. Neurasthenia } \\
\text { Hodgkin's disease } \\
\text { Chronic arthritis } \\
\text { Congenital heart disease. Duo- }\end{array}$ \\
\hline 85 & 4.5 & 85 & 4.53 & 6,040 & $\begin{array}{l}\text { Arteriosclerosis. Syphilis. Chole- } \\
\text { cystitis. Cholelithiasis }\end{array}$ \\
\hline $\begin{array}{l}87 \\
88 \\
90 \\
91 \\
92\end{array}$ & $\begin{array}{l}5.4 \\
5.7 \\
5.1 \\
4.8 \\
7.1\end{array}$ & $\begin{array}{l}85 \\
82 \\
90 \\
95 \\
48\end{array}$ & $\begin{array}{l}4.85 \\
5.25 \\
4.90 \\
6.30 \\
2.57\end{array}$ & $\begin{array}{r}18,080 \\
9,800 \\
7,100 \\
13,700 \\
9,400\end{array}$ & $\begin{array}{l}\text { Psychasthenia. Peptic ulcer } \\
\text { Cardiac decompensation. Syphilis } \\
\text { Luetic aortitis } \\
\text { Infectious arthritis } \\
\text { Chronic nephritis. Plumbism } \\
\text { Generalized arteriosclerosis }\end{array}$ \\
\hline $\begin{array}{r}94 \\
95 \\
101 \\
102 \\
103 \\
104\end{array}$ & $\begin{array}{l}5.3 \\
4.5 \\
6.1 \\
4.5 \\
5.3 \\
4.6\end{array}$ & $\begin{array}{l}90 \\
88 \\
88 \\
98 \\
75 \\
83\end{array}$ & $\begin{array}{l}4.70 \\
4.85 \\
4.69 \\
5.35 \\
3.96 \\
4.83\end{array}$ & $\begin{array}{r}7,400 \\
9,200 \\
8,900 \\
6,320 \\
7,520 \\
10,200\end{array}$ & $\begin{array}{l}\text { Mediastinal tumor } \\
\text { Arteriosclerotic heart disease } \\
\text { Arteriosclerotic heart disease } \\
\text { Syphilis } \\
\text { Luetic aneurysm } \\
\text { Angina pectoris. Coronary scle- } \\
\text { rosis. Bronchial asthms }\end{array}$ \\
\hline $\begin{array}{l}105 \\
107\end{array}$ & $\begin{array}{l}9.5 \\
3.7\end{array}$ & $\begin{array}{r}130 \\
90\end{array}$ & $\begin{array}{l}6.18 \\
4.43\end{array}$ & $\begin{array}{r}16,450 \\
9,050\end{array}$ & $\begin{array}{l}\text { Congenital heart disease } \\
\text { Psychasthenia }\end{array}$ \\
\hline \multicolumn{6}{|c|}{ Female } \\
\hline 10 & 4.7 & 84 & 4.47 & 9,480 & Neurasthenia. Hyperventilation \\
\hline $\begin{array}{l}19 \\
33 \\
35 \\
39 \\
41\end{array}$ & $\begin{array}{r}14.3 \\
4.5 \\
4.3 \\
4.9 \\
5.7\end{array}$ & $\begin{array}{r}180 \\
68 \\
97 \\
81 \\
100\end{array}$ & $\begin{array}{r}10.10 \\
3.93 \\
4.61 \\
4.30 \\
5.10\end{array}$ & $\begin{array}{l}9,200 \\
8,840 \\
5,500 \\
8,200 \\
6,400\end{array}$ & $\begin{array}{l}\text { tetany } \\
\text { Polycythemia } \\
\text { Cyst of the liver } \\
\text { Purpura hemorrhagica } \\
\text { Questionable spinal cord tumor } \\
\text { Carcinoma of the ovary with as- }\end{array}$ \\
\hline 59 & 4.9 & 88 & 5.01 & 7,810 & Mitral heart disease. Paroxysmal \\
\hline $\begin{array}{l}60 \\
63 \\
67 \\
68 \\
78\end{array}$ & $\begin{array}{l}3.9 \\
4.7 \\
3.8 \\
5.6 \\
5.3\end{array}$ & $\begin{array}{l}80 \\
85 \\
45 \\
85 \\
75\end{array}$ & $\begin{array}{l}4.53 \\
4.32 \\
4.20 \\
5.08 \\
4.95\end{array}$ & $\begin{array}{r}7,120 \\
\mathbf{5 , 5 0 0} \\
13,400 \\
\mathbf{9 , 2 0 0} \\
\mathbf{6 , 1 0 0}\end{array}$ & $\begin{array}{l}\text { Exophthalmic goiter } \\
\text { Arteriosclerotic hesrt disease } \\
\text { Rheumatic heart disease } \\
\text { Ovarian tumor. Blindness } \\
\text { Carcinoms of the head of the pan- }\end{array}$ \\
\hline $\begin{array}{r}83 \\
97 \\
98 \\
99 \\
100\end{array}$ & $\begin{array}{l}4.3 \\
6.0 \\
5.2 \\
5.4 \\
6.1\end{array}$ & $\begin{array}{l}90 \\
76 \\
76 \\
88 \\
84\end{array}$ & $\begin{array}{l}4.90 \\
4.10 \\
4.49 \\
4.50 \\
4.30\end{array}$ & $\begin{array}{r}8,800 \\
12,300 \\
6,640 \\
7,000 \\
8,850\end{array}$ & $\begin{array}{l}\text { Sinusitis } \\
\text { Adenocarcinoms of the kidney } \\
\text { Atrophic arthritis } \\
\text { Chronic nephritis with edema } \\
\text { Chronic arthritis }\end{array}$ \\
\hline
\end{tabular}

* Classified both with the cases of anemia and leukopenia for statistical analysis.

$\dagger$ Classified both with cases of leukopenia and leukemia for statistical analysis.

$\ddagger$ The number of the case refers to a patient, the letter to successive samples from the same patient. 
abnormal physiological conditions (Table I). The amount of hemoglobin, the erythrocyte, and the leukocyte counts presented variations beyond those usually found in normal individuals. Especial attention was directed to patients suffering from anemia, leukopenia, and leukemia. It should be pointed out that there are several instances in which serial specimens were taken from the same patients. These were chosen because of the nature of the pathological changes, the effects of treatment, and the variations in the percentage of hemoglobin and blood counts. (Table I, Cases $6,17,20$, and 26.) which did not fall into the foregoing classifications were grouped and studied together. Because of the reduced number of cases, this naturally decreased the reliability of any statistical procedure which might be used. By the use of selective grouping, however, it was possible to determine the effect of various concealed factors on the analysis of the total number of cases (Table II).

There was some overlapping among the cases of anemia and leukopenia. Of the eight cases of anemia, four had leukocyte counts so low that they were also classified with the leukopenia

TABLE II

Means and standard deviations of data given in Table I

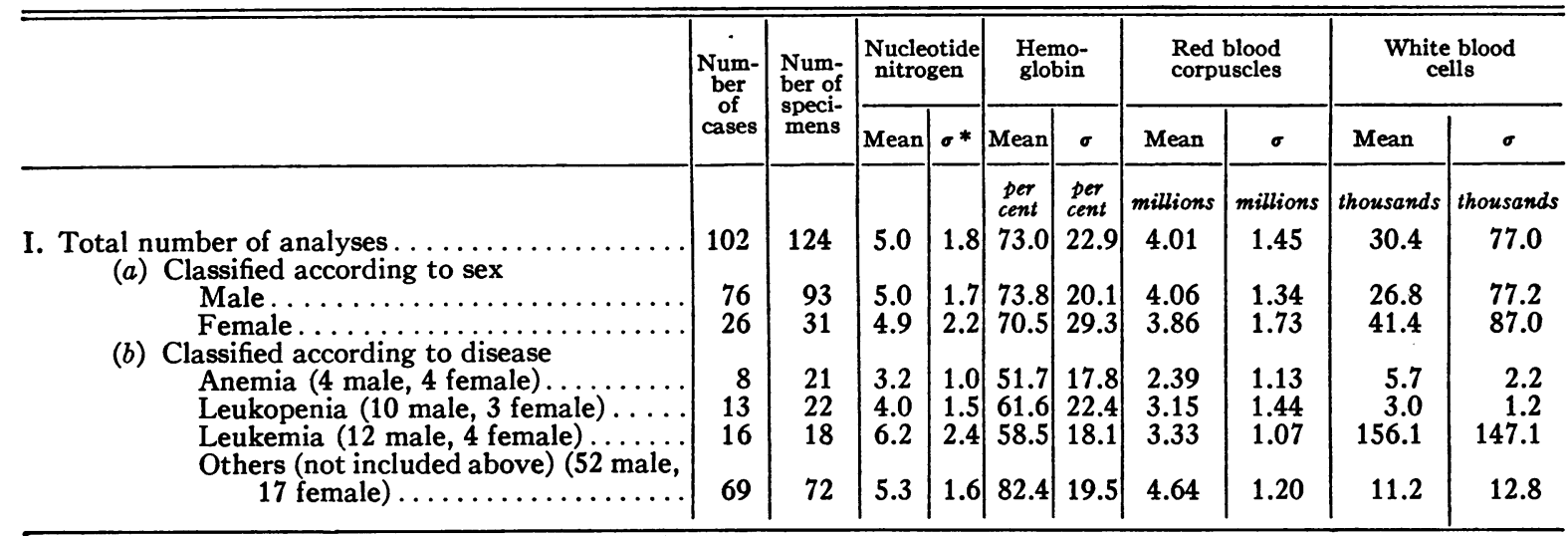

* The standard deviation $(\sigma)$ is the square root of the arithmetic mean of the squares of all deviations; deviations being measured from the arithmetic mean of the observations $\sigma=\sqrt{\frac{E x^{2}}{n}}$. (Yule, G. U., An Introducton to the Theory of Statistics. Charles Griffin \& Co., London, 1927, 8th ed., p. 134).

In order to study the nucleotide nitrogen, the quantitative method of Kerr and Blish (5) was used. It was found to be satisfactory. The hemoglobin values were determined by using a Sahli hemoglobinometer (100 per cent equals 14 grams hemoglobin per $100 \mathrm{cc}$.), and the usual procedures were followed in making blood counts.

The data for each test were correlated with the amount of nucleotide nitrogen in each $100 \mathrm{cc}$. of whole blood. The Pearson coefficient of correlation was used.

In order to treat the material statistically, the data were classified according to sex. They were then grouped and studied according to certain diagnoses; i.e., pernicious anemia, leukopenia (cases in which the leukocyte count was less than 5000 per c. mm.), and leukemia. Those cases cases. This double classification occurred in nine instances. In one instance, that of a case of leukemia under treatment (Case 106), the first leukocyte count was so low that the blood was grouped with the leukopenia as well as with the leukemia cases.

When the total number of cases is considered, there are significant correlations (Table III) between the amount of nucleotide nitrogen and the percentage of hemoglobin, red blood corpuscle count, and white cell count. This does not indicate a cause and effect relationship. As one value increases; i.e., the percentage of hemoglobin, the red blood corpuscle count, or the white blood cell count, the amount of nucleotide nitrogen also increases.

When the data are classified according to sex, 
TABLE III

Correlations between the amount of nucleotide nitrogen per $100 \mathrm{cc}$. of whole blood and per cent of hemoglobin and total red and white blood counts, the sample having been classified as in Table II (124 specimens from 102 patients)

\begin{tabular}{|c|c|c|c|c|c|}
\hline & \multirow{2}{*}{$\begin{array}{c}\text { Num- } \\
\text { ber } \\
\text { of } \\
\text { cases }\end{array}$} & \multirow{2}{*}{$\begin{array}{l}\text { Num- } \\
\text { ber of } \\
\text { speci- } \\
\text { mens }\end{array}$} & \multicolumn{3}{|c|}{$\begin{array}{l}\text { Correlations of nucleotide } \\
\text { nitrogen with }\end{array}$} \\
\hline & & & $\begin{array}{l}\text { Hemo- } \\
\text { globin }\end{array}$ & $\begin{array}{l}\text { Red } \\
\text { blood } \\
\text { corpus- } \\
\text { cles }\end{array}$ & $\begin{array}{l}\text { White } \\
\text { blood } \\
\text { cells }\end{array}$ \\
\hline 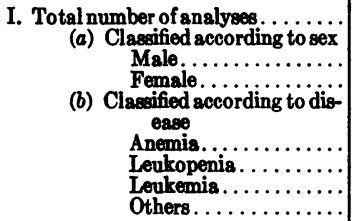 & $\begin{array}{r}102 \\
76 \\
26 \\
\\
8 \\
8 \\
16 \\
13 \\
69\end{array}$ & $\begin{array}{r}124 \\
93 \\
31 \\
\\
21 \\
22 \\
18 \\
72\end{array}$ & $\begin{array}{r}0.584 \\
0.447 \\
0.786 \\
\\
0.888 \\
0.798 \\
-0.757 \\
0.969\end{array}$ & $\begin{array}{l}0.572 \\
0.508 \\
0.690 \\
\\
0.796 \\
0.856 \\
0.096 \\
0.668\end{array}$ & $\begin{array}{r}0.491 \\
0.528 \\
0.214 \\
\\
0.276 \\
0.112 \\
0.770 \\
-0.295\end{array}$ \\
\hline
\end{tabular}

practically the same correlations as were obtained in the analysis of the total number of cases, hold for the males, but not for the females. The larger proportion of males, of course, affects the total picture.

In considering the correlations when the data are grouped according to diagnosis, it is found that in the case of the patients with anemia, although there are four men and four women represented, and the number of specimens divide as to sex into fourteen from men and seven from women, the correlations follow those for women rather closely. It appears that in these cases of anemia, when the amount of hemoglobin and the number of red blood corpuscles are very low, the nucleotide nitrogen is also low. An increase in hemoglobin and red blood corpuscles is accompanied by a simultaneous increase in the nucleotide nitrogen content. There is no significant correlation between nucleotide nitrogen and the white blood cell count in the group of cases of anemia.

In the specimens showing leukopenia, the same correlations hold as for the cases of anemia. In this instance, it must be remembered that there is some overlapping of specimens; i.e., nine samples of blood common to both pernicious anemia and leukopenia.

When considering the cases of leukemia, there is a significant negative correlation between the nucleotide nitrogen and the hemoglobin content of the blood. There is no relationship at all between the nucleotide nitrogen and the number of red blood corpuscles. On the other hand, there is a significant positive correlation between the nucleotide nitrogen and the number of white blood cells. It will be noted (Table II) that the mean hemoglobin and the red blood corpuscle content do not differ appreciably from either the anemic or the leukopenic groups, but that, as would be expected, the mean number of white blood cells is very high with a large variation $(M=156,000$; S. D. $=147,100)$. The mean amount of nucleotide nitrogen is also high when compared with other values in the table $(M=6.2, \mathrm{~S} . \mathrm{D} .=2.4)$. It is evident from the positive correlation of 0.770 that these high values for nucleotide nitrogen must be in some way associated with the increased white blood cell count.

In the group of other diagnoses, the nucleotide nitrogen is significantly correlated with both the hemoglobin and the number of red blood corpuscles. The correlation with the white blood cells, although negative, is not statistically significant.

\section{DISCUSSION}

The correlations between nucleotide nitrogen and the percentage of hemoglobin and the red blood corpuscle count are high in all the conditions which were studied, except in leukemia. This indicates that in those conditions in which the number and volume of the red blood corpuscles are great in comparison to that of the white blood cells, the amount of nucleotide in whole blood is practically dependen $\bar{t}$ upon the number and volume of the red blood corpuscles (3). In other words, the amount of nucleotide which may be present in the white blood cell would be masked completely by the larger quantity of nucleotide which is confined to the red blood corpuscles.

The correlation coefficient of 0.770 between nucleotide nitrogen and white blood cell count indicates that in leukemia the leukocytes and possibly the plasma may participate in elevating the nucleotide content of whole blood. An examination of the cases of leukemia demonstrates variations from the mean which may be associated with the progressive or regressive phase of the leukemia. This may indicate the presence of nucleotide in the white blood cell, as well as nucleo- 
tide in the plasma. The nucleotide of the plasma may be derived from the breakdown of the nucleic acid which is contained within the nucleus of the white blood cell. Certain experiments in progress, where the nucleotide nitrogen of both the whole blood and the plasma was determined, indicate that there is an appreciable amount of nucleotide nitrogen in the plasma of leukemic bloods. The high nucleotide content of leukemic bloods possibly accounts for the high uric acid values so often observed in leukemia.

\section{SUMMARY}

1. The nucleotide nitrogen content of 124 samples of pathological blood obtained from 102 patients was studied. The values were correlated with the percentage of hemoglobin, the red blood corpuscle, and white blood cell counts.

2. The correlations between nucleotide nitrogen and the percentage of hemoglobin and the red blood corpuscle count are high in all conditions, except in leukemia. A high correlation was found between nucleotide nitrogen and the white blood cell count in leukemia. An explanation for this is offered.

It is a pleasure to acknowledge the assistance of Dr. E. L. Lucia, Assistant Professor of Biometry, Department of Hygiene, University of California, who supervised the statistical analysis and aided in the preparation of this manuscript.

\section{BIBLIOGRAPHY}

1. Rothmann, H., Klinische Untersuchungen über die Adenosinphosphorsäure (Adenin-Nucleotid) in Blut und Galle. Ztschr. f. d. ges. exper. Med., 1931, 77, 22.

2. Buell, M. V., The relation of adenine nucleotide to hemoglobin, hematrocrit, and red cell count in human blood. J. Biol. Chem. (Proc.), 1935, 109, xii.

3. Buell, M. V., The adenine nucleotide content of human blood. I. Determination and content. J. Biol. Chem., 1935, 108, 273.

4. Buell, M. V., and Perkins, M. E., Adenine nucleotide content of blood with a micro analytical method for its determination. J. Biol. Chem., 1928, 76, 95.

5. Kerr, S. E., and Blish, M. E., A method for the determination of nucleotides in blood and muscle. J. Biol. Chem., 1932, 98, 193. 